\title{
The economic optimization of investment into the territorial development of recreation
}

\section{Larysa Hrytsenko}

Doctor of Economics, Associate Professor, Department of Finance and Credit, Sumy State University, Ukraine

\section{Hanna Shevchenko}

Ph.D., Associate Professor, Associate Professor of Management Department, Sumy State University, Ukraine

\section{Katherina Daher}

Ph.D., Assistant Professor at Business School, Lebanese International University, Beirut, Lebanon

\begin{abstract}
In the field of recreational nature management the mechanisms of attraction of investment resources have a particular specificity, which consists in necessity of consideration of objectively existing synergistic relationships between economic, social and environmental components. Recreational nature management based on the use of natural-recreational potential of certain territories foresees a need for state regulation of recreational activity in the regions.

In the article a complex economic assessment of natural-recreational potential of Sumy oblast in Ukraine was carried out, the values of regional recreational rent in districts of Sumy oblast was defined. The character of influence of change of parameters of the objective function of maximization of recreational product on the aggregate magnitude and structure of recreational services is analyzed, in accordance with methodical provisions of application the optimization instrument of dual assessments at use of natural-recreational potential of the territory: an analysis of the limits of sustainability of prices on recreational services that are included or not included to the baseline plan of recreational development in districts of oblast; analysis of limitations on recreational resources on which is absent or available reserve within the framework of defined territory.

Among the main results of conducted complex assessment of natural-recreational potential of Sumy oblast highlighted the following: defined the investment attractiveness of districts of the oblast from the perspective of development in them the recreational activity; determined the volume of investments in development of recreational activity by types of recreational services on districts of oblast; assessed the absolute values and limits of change of local natural-recreational potentials conditioned by the dynamics of prices on recreational services in districts of oblast; determined the limitations of sustainability for constraints on land and labor resources and conditioned by them change in the magnitude of local natural-recreational potential of the territory.
\end{abstract}

Keywords: secondary resources, two-tier economic model, socio-ecological modification, management, Ukraine.

JEL Classification: C61, E22, I18, L83.

DOI: $10.21272 / \mathrm{sec} .1(2) .59-79.2017$.

(C) The Authors, 2017. This article is published with open access at ARMG Publishing.

\section{Introduction}

The completion of Ukraine's transition to market conditions of economy management requires the formation of organizational-economic mechanisms, including those aimed at optimizing the attraction of investment resources that dialectically combine a set of instruments and levers of state regulation and market selfregulation based on the principles of sustainability and balance and designed to ensure vital functions of people. In the field of recreational nature management the mechanisms of attraction of investment resources have a particular specificity, which consists in necessity of consideration of objectively existing synergistic relationships between economic, social and environmental components. Recreational nature management based on the use of natural-recreational potential of certain territories foresees a need for state regulation of 
recreational activity in the regions on the basis the action of market laws and the laws of conservation and restoration social and natural resources.

Thus, the actuality of theme of this study is an objective necessity of further scientific rationale and improvement of the mechanism of optimization of processes of attraction the investments in the formation and use of natural-recreational potential of the territory based on an assessment of the complex of factors that influence the processes of functioning, optimization and development of recreation at the territorial level.

To the questions of development and practice of implementation of regional policy of recreational development, to the problems of territorial organization of recreational activity, to the peculiarities of development of territorial-recreation systems, to the assessment of recreational capacity and natural-recreational potential of the territories devoted the works of Ukrainian scientists, in particular, V. S. Kravtsiv, L. S. Hryniv, and M. V. Kopach, S. P. Kuzyk (1999), T. F. Panchenko (2001), I. M. Yakovenko (2005), V. M. Kysly (2008), and works of foreign scientists: V. S. Kachanov, L. V. Panasyk, and N. S. Shukhov (1989), V. I. Azar, J. Dehez, S. Lyzer (2014), H. R. Hall, C. McCarty, and M. W. Clark (2014), S. Andkjer, J. Arvidsen (2015), T. H. Lee, F.-H. Jan, and G. W. Huang (2015), J. Li, W. Zhang, H. Xu, and J. Jiang (2015), and many others. Thus, the article by H. R. Hall, C. McCarty, and M. W. Clark (2014) analyses the principles of regulatory protection and definition for recreational uses of Florida lakes. The work by J. Dehez, S. Lyzer (2014) develops a multivariate analysis and cost analysis in outdoor recreation planning. The paper of T. H. Lee, F.H. Jan, and G. W. Huang (2015) analyses the influence of recreation experiences on environmentally responsible behavior of economic agents. Despite of the importance and value of conducted national and foreign studies in economic sphere of recreational nature management, the issues of comprehensive approach to consideration of interrelated heterogeneous factors of recreational activity at the territorial level both theoretical-methodological and practical terms are still unresolved. Further understanding of the economic substance of natural-recreational potential of the territory as defined system of elements, interconnections and relationships in the process of satisfaction of the recreational needs through the optimal use of recreational resources is needed.

The purpose of a given research - is the improvement of theoretical-methodological provisions for the economic optimization of investment into the territorial development of recreation in Ukraine on the basis of complex economic assessment of natural-recreational potential.

The main results. According to forecast data of the State Scientific Research and Design Institute of Urban Planning [17], according to the "General concept of planning scheme in Ukraine" is predicted a gradual development of recreational of territories, which for the period to 2026 will constitute $48 \%$ (3665,0 thousand hectares) with respect to the potential resources (7669,0 thousand hectares $-12.8 \%$ of the country) (Table 1$)$.

Table 1. Dynamics of perspective development of wellness and recreational areas* in regions of Ukraine to 2026

\begin{tabular}{|c|l|l|c|c|}
\hline No & \multicolumn{1}{|c|}{ Region } & \multicolumn{1}{|c|}{ Oblasts as part of regions } & $\begin{array}{c}\text { Potential recreational } \\
\text { and wellness territo- } \\
\text { ries, thousand } \\
\text { hectares }\end{array}$ & $\begin{array}{c}\text { Recreational and well- } \\
\text { ness territories that } \\
\text { being developed, } \\
\text { thousand hectares }\end{array}$ \\
\hline 1 & & \multicolumn{1}{|c|}{ Ukraine } & 7669.0 & 3665.0 \\
\hline 2 & Donetskyy & Donetska, Luhanska & 355.8 & 236.1 \\
\hline 3 & Prydniprovskyy & $\begin{array}{l}\text { Dnipropetrovska, } \\
\text { Zaporizka, Kirovohradska }\end{array}$ & 270.8 & 657.8 \\
\hline 4 & Skhidnyy & Poltavska, Sumska, Kharkivska & 944.0 & 191.0 \\
\hline 5 & Tsentralnyy & Kyyvska, Cherkaska & 430.0 & 438.1 \\
\hline 6 & Polisskyy & $\begin{array}{l}\text { Volynska, Zhytomyrska, Rivnenska, } \\
\text { Chernihivska }\end{array}$ & 1649.4 & 460.0 \\
\hline 7 & Podilskyy & Vinnytska, Ternopilska, Khmelnitska & 765.9 & 398.0 \\
\hline 8 & Prychornomorskyy & $\begin{array}{l}\text { AR Krym, Mykolayvska, Odeska, } \\
\text { Khersonska }\end{array}$ & 618.7 & 948.0 \\
\hline 9 & Karpatskyy & $\begin{array}{l}\text { Zakarpatska, Lvivska, } \\
\text { Ivano-Frankivska, Chernivetska }\end{array}$ & 2634.4 & \\
\hline
\end{tabular}

*According to the Land Code of Ukraine $(\mathrm{Ch} .8,9)[11]$ within its territory among the various categories of land, the lands for recreational purposes are allocated that have natural curative properties, and recreational land that are used for recreation of population, tourism and conducting sporting events. 
In the conditions of instability of national economy, the uncertainty of many macroeconomic and social processes, arises a problem of adaptation of the territorial socio-economic systems to external changes. In ensuring the solution of this problem it is important to establish high national socio-economic priorities and objectives of state regulation in the sphere of recreation and tourism (as defined in the laws of Ukraine "On resorts" [15], "On Tourism" [16], etc.), and as well optimization of processes of investment maintenance of territorial development of recreation.

One of the main results of theoretical studies of the essence of natural-recreational potential (NRP) of the territory is the conclusion about extremely complex multifaceted character of its economic assessment. Economic assessment of NRP of the territory is a component of the relevant organizational-economic mechanism and represents the value expression of maximum effect, obtained by the subjects of naturalrecreational activity within a given territory taking into account social and environmental constraints. Most difficult part is to develop a complex approach to economic assessment of NRP of the territories which according to the situation maximally is taking into account all potential opportunities of the territory to render natural-recreational services. By drawing parallels and by finding common features between economic potential and NRP of the territory, in our opinion, broadly defined natural-recreational potential comprises in its structure:

$>$ industrial-infrastructural and investment potential (fixed, revolving funds and etc., the possibility of increase within a given territory);

$>$ labor potential (staff, managerial personnel, opportunity of professional development of personnel in the framework of the recreational activity of the territory);

$>$ natural-resource and ecological potentials (natural-climatic conditions, natural-recreational resources, the possibility of expanding of recreational activity without threat of infringement of natural balance within a given territory, etc.);

$>$ scientific-technological and innovation potential (the ability to generate new knowledge and information within the framework of recreational activity of a given territory).

The practice proves that the recreational environment can have high quality with insufficient naturalresource potential, but with high quality elements of social, technological and cultural environments. Characteristically, that inverse relationship nearly is not observed. Thus, the best recreational resources will not be properly used at a low level of development of other sectors of the recreational environment [23, p. 25]. Consequently, by the recognition of resource component as a basis of formation of NRP of the territory it should be stressed that the expediency of application exactly a complex approach to economic assessment of the system "NRP of the territory", which will allow: to give in value terms the total value of a given potential, to set the proportion of each element in the structure of the potential, to find the degree of use of the potential and so on. On the basis of determination of these values becomes possible the creation of effective mechanisms for managing and developing natural-recreational activity within a particular region.

It should be noted that one of the most effective approaches to the exercising of complex economic evaluation is a modeling. In the work [7, p. 49-51] are examined the examples of application of optimization models when determining socio-economic effectiveness of tourist-recreational activities through the category of "potential". Such the potential, in the opinion the authors, is a set of socio-economic relations that are implemented in order to ensure the most possible level of activity of each member of society. "In this the society is granted the new quality of system, which significantly increases the effectiveness of the entire socioeconomic and productive activities of people and ensure the comprehensive personal development as selfworth, as the goal of all system life of society". To solve the problem of formalizing the objective function recreational activity is extremely difficult. Such function is system-wide concept that includes the formation and development of both socio-economic and natural potential. Its formalization is one of the fundamental economic problems in the sphere of theory and practice of recreation. Some of approximation to its solution may be systemic modeling, i.e. the development of the complex optimization models, based on the theory of multistage (iterative) optimization. In this the search for optimal functioning of the recreational system can be significantly facilitated if the adequate organizational-economic mechanism is created in the sphere, and the optimizing property of which will directly contribute to achieving maximum revitalizing effect of tourist-recreational activities. For such mechanisms can be attributed, for example, optimal pricing, rent payments and rent evaluations of recreational services of target assignment. 
Considering the above, in our opinion, the use of exactly optimization model of mathematical programming at imposing certain limitations on its parameters that correspond to the real terms of the national economy, allows for a complex assessment of NRP of the territory taking into account type of characteristics of recreation as well as relevant interrelation of natural, human and created capital. In this study is proposed to use the optimization model of linear programming by L. V. Kantorovich [8; 9]. The most suitable indicator of efficiency of the economic system and therefore the criterial parameter in the model of economic potential is the gross regional product [22, p. 877] (with respect to the recreational sector of the territory the role of the indicator takes a regional recreational product intended for final consumption).

Given optimization model will enable to take into account:

$>$ the maximum amount of interests (in a certain sense - levels) in the field of natural-recreational activity in the region;

$>$ the situational approach, i.e. the results obtained by means of this model may vary depending on the dynamics of external and internal environments;

$>$ the specific variety the recreational activity;

$>$ enhancing the role of human resources in relation to natural, human and physical capital;

$>$ the additional options of formation and use of NRP;

$>$ the possibility of realization the certain balancing of recreational resources.

Mathematical description of the optimization model [19]

\section{Introduction of designations:}

$L$ - gross regional product derived by enterprises of natural-recreational sphere ( an indicator of economic assessment of NRP of the territories), thousand UAH.

$P_{h}, P_{r}, P_{s}, P_{e}$ - the market marginal price of recreational services considering the most unfavorable combination of resources usage (factors), euro, respectively to type: $P_{h}$ - health care recreation (sanatorium type), $P_{r}-$ prolonged recreation (at the bases and rest houses, boarding houses), $P_{s}$ - sports tourism (at the sports and training centers, sports meetings, etc.), $P_{e}$ - the ecological tourism ( the recuperation by visiting the ecosystems: green, agriculture, forest, nature reserve and route tourism), euro/service. The integration of all types of recreational diversity in these four types is advisable in view of simplifying the very complex iterative calculations, and to conduct of practical research on the example of the region for which recreational activity is not traditional and therefore requires development of types in the future.

$x_{h}, x_{r}, x_{s}, x_{e}$ - the amount of rendered recreational services of certain type in the region during the year, thousand units.

$N$ - overall land area of the recreational purpose (the land is the basis of concentration of manifestation the utilities of natural-recreational resources), hectares.

$N_{h}, N_{r}, N_{s}, N_{e}$ - area of land for recreational purpose calculated per one recreational services according to environmental capacity of a particular type of recreational land at formation of and provision of recreational services in the region during the year, respectively: $N_{h}$ - units of services of health care recreation, $N_{r}-$ units of services at rest houses, $N_{s}$ - units of services of sports type recreation, $N_{e}$ - units of services of ecological type recreation, hectares / unit of services per year.

$H$ - the total number of human resources that may be involved in the formation and provision of recreational services in the region, people.

$H_{h}, H_{r}, H_{s}, H_{e}$ - the number of human resources that have properties in accordance with requirements of the provision of quality recreational services: the level of special education, the level of hospitality etc., calculated on the basis of labor input of certain types of services (persons), which are provided in the region during the year, respectively: $H_{h}$ - units of services of health care recreation, $H_{r}$ - units of services at rest houses, $H_{s}$ - units of services of sports type recreation, $H_{e}$ - units of services of ecological type recreation.

$K$ - the total amount financial investments that may be involved in the formation and provision of recreational services in the region, thousand euro.

$K_{h}, K_{r}, K_{s}, K_{e}$ - financial investment in the formation and provision of recreational services in the region during the year, respectively: $K_{h}$ - units of services of health care recreation; $K_{r}$ - units of services at rest 
houses, $K_{s}$ - units of services of sports type recreation, $K_{e}$ - units of services of ecological type recreation, euro/ unit of services per year.

In broad sense, the parameter $\mathrm{K}$ is directed to the formation of material-technical base of natural-recreational complex (the recreational infrastructure): fixed assets, with which is carried the direct production, provision of recreational services and sale of related goods to tourists as well as auxiliary means labor that does not directly take participation in recreational process, however, affect the conditions of recreation.

2. Formulation of the objective function:

$$
L=P_{h} \cdot x_{h}+P_{r} \cdot x_{r}+P_{s} \cdot x_{s}+P_{e} \cdot x_{e} \rightarrow \max
$$

Such a formulation of the objective function corresponds to the desire of recreational enterprises to maximize their profits, and is aimed at implementation of investment policy of the region: if the investor would know the exact value of the market NRP, it will focus on the number of sales, corresponding to the maximum demand for recreational services in a particular region (the market NRP of the territory). It should be noted that creation of additional demand for investment of general economic business and recreationaltourist purpose is one of the main economic functions of recreational sphere in the region. Receipts of foreign currency from the sale of recreational product are means to settlement of payments imbalance of the region, besides the sector also stimulates an export of goods.

Should be emphasized that in making strategic decisions in natural-recreational sector the regional management bodies come out of that the purpose of functioning of the system "NRP" subordinated to purpose of the system of higher level - "economic potential" of the territory. In this an indicator of NRP of the territory is a GDP, derived by recreational sector of the region as well as increase in regional GDP considering the index of growth of human capital and related ecological indicator during the year. Since the use of NRP in practice imply the formation of appropriate long-term development programs, the time factor is taken into account by discounting the annual values of NRP.

3. Imposition of restrictions to objective function:

$$
\left\{\begin{array}{l}
N_{h} \cdot x_{h}+N_{r} \cdot x_{r}+N_{s} \cdot x_{s}+N_{e} \cdot x_{e} \leq N \\
H_{h} \cdot x_{h}+H_{r} \cdot x_{r}+H_{s} \cdot x_{s}+H_{e} \cdot x_{e} \leq H \\
K_{h} \cdot x_{h}+K_{r} \cdot x_{r}+K_{s} \cdot x_{s}+K_{e} \cdot x_{e} \leq K
\end{array}\right.
$$

4. The introduction of designations according to the conditions of duality:

$z_{N}, z_{H}, z_{K}$ - factorial proportions of marginal prices of recreational services that generated by the cost method considering rate of return per unit of service, euro, respectively: $z_{N}-$ the share of natural factor, $z_{H}-$ the share of human factor, $z_{K}-$ the share of financial factor.

5. The formulation of dual function:

$$
L_{d}=N \cdot z_{N}+H \cdot z_{H}+K \cdot z_{K} \rightarrow \min
$$

$L_{d}$ - the function in accordance with the conditions of duality PRP assessment area. Its essence is to minimize of their expenses by recreational enterprises of the region. Thus, the dual function of NRP reveals the content of economic effectiveness of functioning of the entities of recreational activity, which is to maximize the sales while minimizing the costs for creation the recreational product.

6. The imposition of limitations on dual function:

$$
\left\{\begin{array}{l}
N_{h} \cdot z_{N}+H_{h} \cdot z_{H}+K_{h} \cdot z_{K} \leq P_{h} \\
N_{r} \cdot z_{N}+H_{r} \cdot z_{H}+K_{r} \cdot z_{K} \leq P_{r} \\
N_{s} \cdot z_{N}+H_{s} \cdot z_{H}+K_{s} \cdot z_{K} \leq P_{s} \\
N_{e} \cdot z_{N}+H_{e} \cdot z_{H}+K_{e} \cdot z_{K} \leq P_{e}
\end{array} .\right.
$$

The given system of inequalities reflects summary resources assessment used in the creation of recreational services. In addition, it is possible to identify and carry out further analysis of price limits on certain resources that traditionally grouped into three categories: natural, human and financial resources (or capital). 
7. The formulation of conditions of analysis of coefficients of the objective function as well as limitations on resources:

$$
L=\left(P_{h}+\Delta P_{h}\right) \cdot x_{h}+\left(P_{r}+\Delta P_{r}\right) \cdot x_{r}+\left(P_{s}+\Delta P_{s}\right) \cdot x_{s}+\left(P_{e}+\Delta P_{e}\right) \cdot x_{e} \rightarrow \max ,
$$

where $\Delta P_{h}, \Delta P_{r}, \Delta P_{s}, \Delta P_{e}$ - the magnitude of price changes on recreational services, in accordance to recreational subsystems: $\Delta P_{h}$ - health care, $\Delta P_{r}$ - prolonged rest, $\Delta P_{s}$ - sports, $\Delta P_{e}$ - ecological.

The coefficients of the objective function is a the averaged prices for the recreational services in a particular region, that are calculated by methods of market, indirect market or indirect non-market evaluation - depending on the stage of development of market of the recreational services. The current state of the recreational industry in Ukraine allows to speak about the existence of quasi-market relations in traditional recreation regions and elite types of recreation and the embryonic state of the recreational market - in other regions and relative to social and ecological directed recreation.

In this situation in the formulation of conditions of price changes the crucial importance in the market of recreational services will have a factor of growth in effective demand of population. At present decrease in aggregate demand for domestic of recreational product is explained by complication of socio-economic situation in the country as well as low quality of services in the traditional recreational regions and the underdevelopment of recreational sector in other territories. In conditions of development of economy one of the ways out from the crisis for the recreational sector is to bring to match with international standards the prices and quality of recreational services, modernization of material-technical base of recreation, expansion of the circle of consumers by improving the welfare of local people and attraction of foreign tourists.

The dynamics of limitations on resources is also explained both by market factors and regulatory factors. In formulating the limitations on resources two cases are considered: a) the resources on which there is no reserve; $b$ ) resources on which there is a reserve.

Thus, if during the iterative study would be determined that, for example, limitations on the labor force does not foresee a reserve, then it will affect the amount of recreational services and therefore by the amount of NRP. A change in the amount of resources on which there is reserve will not affect the magnitude of PRP.

$$
\left\{\begin{array}{c}
N_{h} \cdot x_{h}+N_{r} \cdot x_{r}+N_{s} \cdot x_{s}+N_{e} \cdot x_{e} \leq N+\Delta N \\
H_{h} \cdot x_{h}+H_{r} \cdot x_{r}+H_{s} \cdot x_{s}+H_{e} \cdot x_{e} \leq H+\Delta H, \\
K_{h} \cdot x_{h}+K_{r} \cdot x_{r}+K_{s} \cdot x_{s}+K_{e} \cdot x_{e} \leq K+\Delta K
\end{array}\right.
$$

where $\Delta N, \Delta H, \Delta K$ - the magnitude of changes of the resources, accordingly: natural, human and financial. The change $\Delta$ can have both positive and a negative value.

The results of approbation of proposed complex approaches to the economic assessment of NRP of the territory are presented below.

The complex economic assessment of natural-recreational potential of the territory that was conducted on the basis the model we have developed on the example of Sumy region that does not belong to traditional of recreational territories, however, in our opinion, possesses due potential to meet the recreational needs of the population. The local potentials of administrative districts of Sumy region were assessed, where expedient organization of recreational activity on the basis of appropriate natural resources, taking into account the entire complex of relationships between all concerned parties and objects of recreational activity. At the same in the framework of this research was analyzed prolonged rest outside the towns of oblast. By summation of local potentials was received total value of NRP of Sumy region.

The first stage of complex assessment of NRP of the territory is the allocation on it recreational areas according to territorial-administrative basis, - Sumy region comprises 18 administrative districts. Then through zoning of the territory each of the districts we get the micro-territory for the organization of recreational activity. In this are distinguished four types of micro-territory in each of the administrative regions of the oblast: the most valuable, valuable, not valuable micro-territory and not recreational specialization.

In calculating the NRP of the Sumy region were used the most valuable areas of the recreational microterritories. As such territories are considered unique territorial complexes - park-monuments of landscape architecture, territories of natural-reserve fund as well as existing recreational objects of the oblast (based on 
the source [21]). This approach does not contradict the priority directions of development tourismrecreational sector in Ukraine: Strategy of development of tourism and resorts for the period to 2026 in Ukraine [14].

Consider the assessment of local NRP of one of the regions on the basis of statistical socio-economic information by the Sumy region. In this the value of parameters, set out below in the system of equations 8 and respectively in the table 2 correspond to the results of the conducted analysis of the structure and the quantities of recreational resources and prices for different types of services of prolonged rest. In particular, in determining the prices of recreational services (duration of 7 days) were taken into account the following factors as: the prices for similar services of recreational-attractive areas where residents of Sumy region traditionally vacationing; the income level of residents of researched area (based on source [20]); the significance of competitive advantages of vacation without substantial transport costs and therefore timeconsuming, acclimatization and so on. In particular, as a basis for establishing prices for recreational services was taken the percentage (12\% - in line with European norms on vacation spending, based on [6]) of annual average income of the population of certain districts of oblast.

In formulating the limitations on financial resources, we previously proceeded from the level of profitability that does not exceed $50 \%$ and meets conditions of normal profits in the recreational sphere. The total amount of financial resources which is calculated as a weighted average (according to the values of the parameters in table 5):

$K=N \cdot\left(K_{h} \cdot N_{h}+K_{r} \cdot N_{r}+K_{s} \cdot N_{s}+K_{e} \cdot N_{e}\right) /\left(N_{h}+N_{r}+N_{s}+N_{e}\right)$.

$K=200$ (50000+35000 $3+40000 \% 3+30000 \odot 5) /(1+3+3+5) ; K \approx 7000000$ euro, - based on the fact that exactly land resources are the basic in the recreational field. The indicated value will vary along with districts of the region in accordance with their level of investment attractiveness.

Table 2. Initial data for the calculation of local NRP and the regional recreational rent in Sumy oblast, in annual terms

\begin{tabular}{|c|c|c|c|c|c|}
\hline \multirow{2}{*}{ Parameter } & \multirow{2}{*}{ Units of measurement } & \multicolumn{4}{|c|}{ The values by districts } \\
\hline & & 1 st district & 2nd district & 3rd district & 4th district \\
\hline$P_{h}$ & Euro/1000 of services & 100000 & 120000 & 100000 & 110000 \\
\hline$P_{r}$ & Euro /1000 of services & 70000 & 90000 & 90000 & 80000 \\
\hline$P_{s}$ & Euro /1000 of services & 80000 & 80000 & 80000 & 80000 \\
\hline$P_{e}$ & Euro /1000 of services & 60000 & 70000 & 60000 & 80000 \\
\hline$N$ & Hectares & 200 & 240 & 180 & 300 \\
\hline$N_{h}{ }^{*}$ & Hectares /1000 of services & 1 & 1 & 1 & 1 \\
\hline$N_{r}$ & Hectares /1000 of services & 3 & 3 & 3 & 3 \\
\hline$N_{s}$ & Hectares /1000 of services & 3 & 3 & 3 & 3 \\
\hline$N_{e}$ & Hectares /1000 of services & 5 & 5 & 5 & 5 \\
\hline$H$ & Persons & 400 & 480 & 420 & 400 \\
\hline$H_{h}{ }^{\text {*** }}$ & Persons /1000 of services & 8 & 8 & 8 & 8 \\
\hline$H_{r}$ & Persons /1000 of services & 4 & 4 & 4 & 4 \\
\hline$H_{s}$ & Persons /1000 of services & 4 & 4 & 4 & 4 \\
\hline$H_{e}$ & Persons /1000 of services & 2 & 2 & 2 & 2 \\
\hline$K$ & Euro & 7000000 & 10000000 & 7000000 & 13000000 \\
\hline$K_{h}$ & Euro /1000 of services & 50000 & 60000 & 50000 & 55000 \\
\hline$K_{r}$ & Euro /1000 of services & 35000 & 45000 & 45000 & 40000 \\
\hline$K_{s}$ & Euro /1000 of services & 40000 & 40000 & 40000 & 40000 \\
\hline$K_{e}$ & Euro /1000 of services & 30000 & 35000 & 30000 & 45000 \\
\hline
\end{tabular}

Notes: *Parameter values $N_{h}, N_{r}, N_{s}, N_{e}$ meet the norms of numbers of maintenance personnel for different recreational objects, based on the source [2]. ${ }^{* *}$ Parameter values $H_{h}, H_{r}, H_{s}, H_{e}$ is the reciprocal to the normative parameters of recreational load on natural complexes according to the types of recreational activity, based on the source [18].

In determining the limitations on human resources was used the following statistical information on researched region (based on source [4]): the number of employed, the level of unemployment, the number of 
employed in the service sector, the number of employed in restaurant and hotel business, the amount of dismissed from that business and so on. It should be noted that the proposal of expanded development of the recreational complex in the region has a positive aspect on creation of new jobs and a partial solution to the problem of unemployment, especially in rural areas. However, it should be reckoned to the quality of human resources and approached selectively to the formation of labor potential in the recreational sphere. It is primarily about the creation of additional competitive advantages over traditional recreational territories, where the question of hospitality, professional expertise in recreational businesses, qualifications of physicians and etc. remain rather problematic. Furthermore, when considering the structure of the unemployed as a potential of future personnel of recreational enterprises should take into account respective alternatives regarding other sectors of the regional economy. In determining the total amount of lands for recreational purpose in the Sumy region were taken into account the following factors: the degree of suitability of recreational land, the proximity of industrial facilities, the development of transport routes, the distance from the oblast center, ecological factors, landscape features and the availability of tourist routes for weekend (based on source [21]). In this the special attention was paid to such nature objects and resources as protected areas of national importance, hydrological nature monuments, park-monuments of garden and park art, sources of mineral waters etc. - in accordance to maximal approach on quality of natural-recreational resources of attractive areas. In this taken into account the pioneerdom of stages of development of recreational sector in Sumy oblast and orientation of recreational needs of the population for obtaining therapeutic and aesthetic effects from the recreation during the prolonged rest "at home", that are equivalent to traditional recreation near the sea or in the mountains.

In other words an integrated approach to achieving the competitiveness of non-traditional of recreational territories compared with traditional regions of recreation is used. Along with to such factors as the lower level of expenses of recreants (especially on transportation), lower level of recreational risks, lack of acclimatization period, the highest level of hospitality compared to similar institutions of rest by "nonnative" regions - in our view, in assessing the NRP one should focus on the minimum gap in the quality of recreational resources (land and natural) of comparable territories.

Thus, according to the formulas (1) and (2) we present the calculation of NRP of one of the districts of Sumy oblast, recorded in the form of system of linear equations (according to the solution of optimizational problems of linear programming [9]):

$$
\left\{\begin{array}{c}
L=0-\left(-100 \cdot x_{h}-70 \cdot x_{r}-80 \cdot x_{s}-60 \cdot x_{e}\right) \\
Y_{N}=200-\left(x_{h}+3 \cdot x_{r}+3 \cdot x_{s}+5 \cdot x_{e}\right) \\
Y_{H}=400-\left(8 \cdot x_{h}+4 \cdot x_{r}+4 \cdot x_{s}+2 \cdot x_{e}\right) \\
Y_{K}=70000-\left(50 \cdot x_{h}+35 \cdot x_{r}+40 \cdot x_{s}+30 \cdot x_{e}\right)
\end{array} .\right.
$$

In Table 3, the values in the upper left corner of each cell are recorded in accordance with the parameters of the system of equations (8). In the lower right corner of cells the calculated parameters are written in accordance with the optimization column, row and cell (in this iteration, respectively: $X_{h}, Y_{H}, \lambda=1 / 8$ ). The rules of filling in a standard table are given in the work [9].

Table 3. Standard form of recording parameters and variables of functiof on local NRP

\begin{tabular}{|c|c|c|c|c|c|c|}
\hline \multirow{2}{*}{$\begin{array}{c}\text { The baseline } \\
\text { variables }\end{array}$} & \multirow[t]{2}{*}{ Free parameter } & \multicolumn{5}{|c|}{ Free variables } \\
\hline & & $X_{h}$ & $X_{r}$ & $X_{s}$ & $X$ & \\
\hline$L$ & 5000000 & -100000 & -70000 & -80000 & -60000 & 25000 \\
\hline$Y_{N}$ & 200 & $-1 / 8$ & $-1 / 2$ & $-1 / 2$ & 5 & $-1 / 4$ \\
\hline$Y_{H}$ & 400 & $\lambda=1 / 8$ & $1 / 2$ & $1 / 2$ & 2 & $1 / 4$ \\
\hline$Y_{K}$ & $\begin{array}{r}7000000 \\
-2500000\end{array}$ & 50000 & -25000 & -25000 & 30000 & -12500 \\
\hline
\end{tabular}

In the next iterations is carried out the replacement of the basic and free variables (Tables 4 and 5), is achieved an optimum in the value of function $L(\mathrm{NRP})-L^{*}$, since a sign of all free variables is positive (Table 
5). In this an equality $L^{*}=L_{d}^{*}$ is fair, i.e. the value of NRP coincides with the value of dual function of minimization of recreational resources.

Thus, the main results of the conducted iterative analysis as follows: $L^{*}=L^{*}{ }_{d}=6800000$ euro; $X^{*}(20000 ; 0$; $60000 ; 0) ; Y^{*}(0 ; 0 ; 3600000) ; Z^{*}(12000 ; 11000 ; 0)$.

That is, the economic assessment of local NRP of Sumy region - 6800000 euro; in the implementation of services of health care (at a price $P_{h}=100$ euro) and sports (at a price $P_{s}=80$ euro) recreation in volume $X_{h}=20000$ units and $X_{s}=60000$ units respectively; resources on which the reserve is depleted - the land $Y_{N}$ and human $Y_{H}$ recreational resources; the savings on investments is $Y_{K}=3600000$ euro; factorial proportions of marginal prices per unit of land and human resources in implementing the unit of recreational services equal $Z_{N}=12$ euro and $Z_{H}=11$ euro respectively.

Table 4. Transfer of limitations on recreational lands to free variables

\begin{tabular}{|c|c|c|c|c|c|c|}
\hline \multirow{2}{*}{$\begin{array}{l}\text { The baseline } \\
\text { variables }\end{array}$} & \multirow{2}{*}{ Free parameter } & \multicolumn{5}{|c|}{ Free variables } \\
\hline & & $Y_{H}$ & $X_{r}$ & $X_{s}$ & $X$ & \\
\hline$L$ & $\begin{array}{r}5000000 \\
1800000 \\
\end{array}$ & 12500 & -20000 & -30000 & -35000 & 57000 \\
\hline$Y_{N}$ & 150 & $-1 / 20$ & $5 / 2$ & $\lambda=2 / 5$ & $19 / 4$ & $19 / 10$ \\
\hline$X_{h}$ & 50 & $1 / 40$ & $-1 / 2$ & $-1 / 5$ & $1 / 4$ & $-19 / 20$ \\
\hline$Y_{K}$ & $\begin{array}{r}4500000 \\
\quad-900000\end{array}$ & $1 / 48000$ & -15000 & 15000 & 17500 & -28500 \\
\hline
\end{tabular}

Table 5. The final iteration of complex assessment of the local NRP of territory

\begin{tabular}{|c|c|c|c|c|c|}
\hline \multirow{2}{*}{$\begin{array}{c}\text { The baseline } \\
\text { variables }\end{array}$} & \multirow{2}{*}{ Free parameter } & \multicolumn{4}{|c|}{ Free variables } \\
\cline { 3 - 6 } & & $Y_{H}$ & $X_{r}$ & $Y_{N}$ & $X_{e}$ \\
\hline$L$ & 6800000 & 11000 & 10000 & 12000 & 22000 \\
\hline$X_{s}$ & 60 & -0.05 & 1 & 0.4 & 1.9 \\
\hline$X_{h}$ & 20 & 0.15 & 0 & -0.2 & -0.7 \\
\hline$Y_{K}$ & 3600000 & -6250 & -5000 & -6000 & -11000 \\
\hline
\end{tabular}

We proceed to determining the value of a regional recreational rent (RRR) in districts of Sumy oblast (the results recorded in Table 12).

Baseline data, as mentioned above, derived from information concerning recreational activity in the Sumy oblast (Table 2). In this for simplification of mathematical optimization procedure, as in the case of calculation of local NRP described above, recording is conducted on 1000 units of services (iteration for the 1st district in Tables 6-8).

According to formula 9 under the terms of optimization of dual function: $L^{*}{ }_{d}=L^{*}$, we will use the iterative filling of Tables 3-5 and respectively - the specific application of simplex-method in calculating of RRR (Tables 6-11).

$$
\left\{\begin{array}{c}
B=\left|L_{d}^{*} ; V_{1} ; V_{2} ; \ldots ; V_{n} ; Z_{H} ; Z_{N}\right| \\
V_{1,2, \ldots, n} \geq 0 \\
Z_{N} \geq 0 ; \quad Z_{H} \geq 0
\end{array},\right.
$$

where $B$ - basis of variables at the final iteration of optimization of dual function $L_{\max }=L^{*}{ }_{d .}$ (optimal use of NRP of the district);

$V_{l, 2, \ldots, n}$ - the variables that correspond to recreational services of the types that are not appropriate to produce in the district without additional organizational arrangements;

$Z_{N}, Z_{H}$ - the value of factorial proportions of marginal prices per unit of land and human resources respectively in implementing the unit of recreational services at the optimum value of $\operatorname{NRP}\left(L_{\max }=L_{d}^{*}\right)$. 
Table 6. Standard form of recording the parameters and variables of dual function

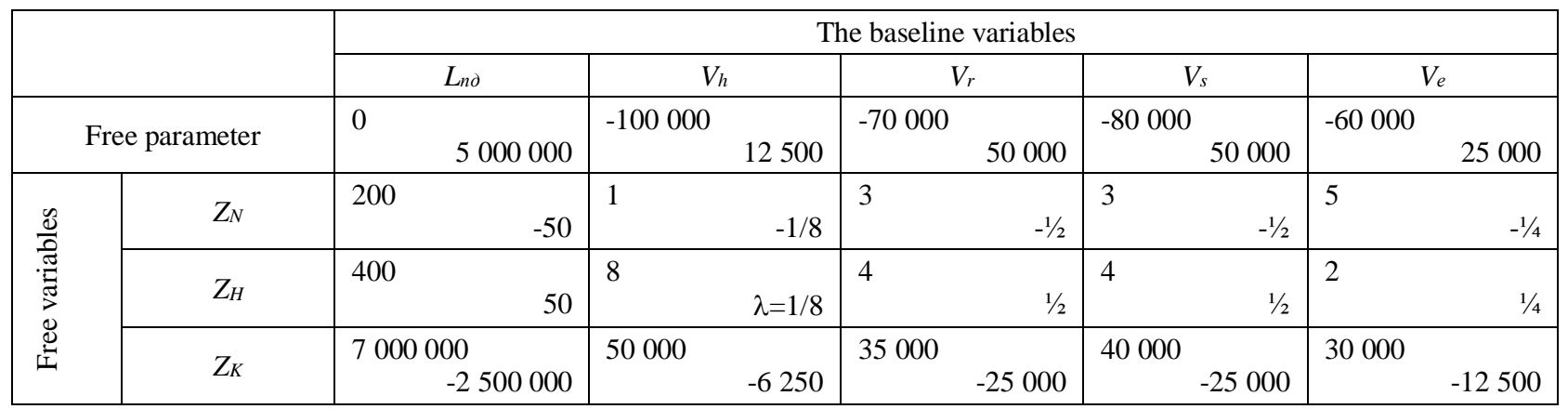

Table 7. Transfer of limitations on recreational lands to baseline variables

\begin{tabular}{|c|c|c|c|c|c|c|c|}
\hline & & \multicolumn{6}{|c|}{ The baseline variables } \\
\hline & & $L_{d}$ & $Z_{H}$ & $V_{r}$ & $V_{s}$ & & \\
\hline \multicolumn{2}{|c|}{ Free parameter } & $\begin{aligned} & 5000000 \\
& 1800000\end{aligned}$ & 12500 & -20000 & $\begin{array}{ll}-30000 & \\
& 12000\end{array}$ & -35000 & 57000 \\
\hline \multirow{3}{*}{ 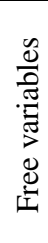 } & $Z_{N}$ & 150 & $-1 / 8$ & $5 / 2$ & $\lambda=2 / 5$ & $19 / 4$ & $19 / 10$ \\
\hline & $V_{h}$ & 50 & $1 / 40$ & $-1 / 2$ & $-1 / 5$ & $1 / 4$ & $-19 / 20$ \\
\hline & $Z_{K}$ & 4500000 -900000 & -6250 & 10000 & 15000 & 17500 & -28500 \\
\hline
\end{tabular}

Table 8. The final iteration of optimization of dual function (1st district)

\begin{tabular}{|c|c|c|c|c|c|c|}
\hline \multirow{2}{*}{} & \multicolumn{5}{|c|}{ The baseline variables } \\
\cline { 2 - 7 } & $L_{d}{ }^{*}$ & $Z_{H}$ & $V_{r}$ & $Z_{N}$ & $V_{e}$ \\
\hline \multicolumn{2}{|c|}{ Free parameter } & 6800000 & 11000 & 10000 & 12000 & 22000 \\
\hline \multirow{3}{*}{$\begin{array}{c}\text { Free } \\
\text { variables }\end{array}$} & $V_{s}$ & 60 & -0.05 & 1 & 0.4 & 1.9 \\
\cline { 2 - 7 } & $V_{h}$ & 20 & 0.15 & 0 & -0.2 & -0.7 \\
\cline { 2 - 7 } & $Z_{K}$ & 3600000 & -6250 & -5000 & -6000 & -11000 \\
\hline
\end{tabular}

The value of free variables $V$ on the final iteration, multiplied by 1000 , display the number of recreational services in the districts. The value of the basic variable $\mathrm{Z}$ on the final iteration, divided by the 1,000 that correspond to factorial proportions of marginal prices on recreational resources calculated per one service (Tables 9-11).

Table 9. The final iteration of optimization of dual function (2nd district)

\begin{tabular}{|c|c|c|c|c|c|c|}
\hline & & \multicolumn{5}{|c|}{ The baseline variables } \\
\hline & & $L_{d}{ }^{*}$ & $Z_{H}$ & $Z_{N}$ & $V_{s}$ & $V_{e}$ \\
\hline \multicolumn{2}{|c|}{ Free parameter } & 9360000 & 13500 & 12000 & 10000 & 17000 \\
\hline \multirow{3}{*}{ 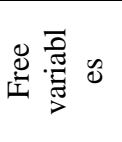 } & $V_{r}$ & 72 & -0.05 & 0.4 & 1 & 1.9 \\
\hline & $V_{h}$ & 24 & 0.15 & -0.2 & 0 & -0.7 \\
\hline & $Z_{K}$ & 5320000 & -6750 & -6000 & -5000 & -8500 \\
\hline
\end{tabular}

Table 10. The final iteration of optimization of dual function (3rd district)

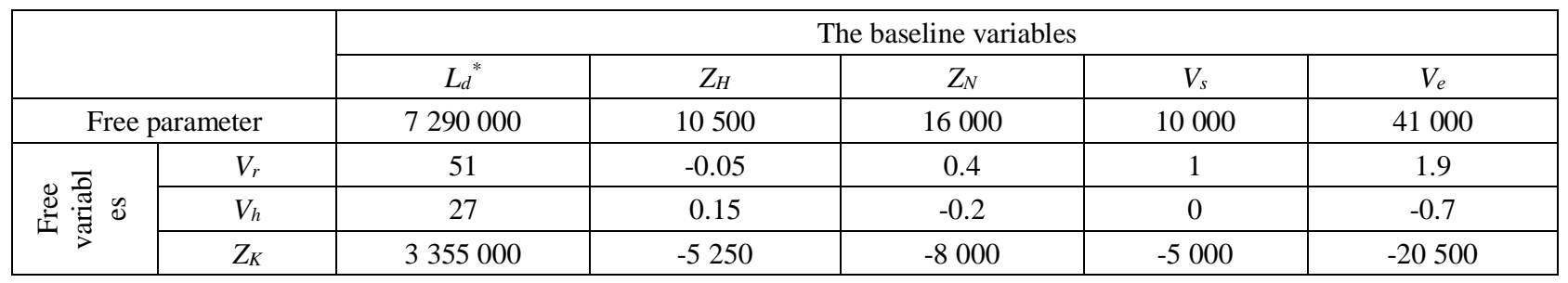

For example, for recreation of health care type, on condition of unboundedness of investment resources (free variable $Z_{K}=0$ ) can be written: 
$N_{h 1} \cdot z_{N}+H_{h 1} \cdot z_{H}=P_{h 1} \Rightarrow$

$\Rightarrow\left\{\begin{array}{c}\overline{Z_{N 1}}=N_{h 1} \cdot z_{N}=x \% \\ \overline{Z_{H 1}}=H_{h 1} \cdot z_{H}=y \% \\ \overline{Z_{N 1}}+\overline{Z_{H 1}}=P_{h 1}=100 \%\end{array}\right.$.

A digital index "1" indicates to the ordinal number of the district in which NRP is assessed.

Similarly, we find the proportions of factorial particles in prices on recreational services of other types and in other districts.

According to the formula 10 for the 1st district, relatively to values of the parameters for the 1 st district obtained in Table 8, for health care recreation (formula 11) and sports recreation (formula 12) we write the equation:

$$
\begin{aligned}
& N_{h 1} \cdot z_{N}+H_{h 1} \cdot z_{H}+K_{h 1} \cdot z_{K}=P_{h 1}, \\
& 1 \cdot z_{N}+8 \cdot z_{H}+50000 \cdot z_{K}=100000 . \\
& N_{s 1} \cdot z_{N}+H_{s 1} \cdot z_{H}+K_{s 1} \cdot z_{K}=P_{s 1}, \\
& 3 \cdot z_{N}+4 \cdot z_{H}+40000 \cdot z_{K}=80000 .
\end{aligned}
$$

Table 11. The final iteration of optimization of dual function (4th district)

\begin{tabular}{|c|c|c|c|c|c|c|}
\hline \multicolumn{2}{|c|}{} & $L_{d}{ }^{*}$ & $Z_{H}$ & $V_{r}$ & $V_{s}$ & $Z_{N}$ \\
\hline \multicolumn{2}{|c|}{ Free parameter } & 8230000 & 12368 & 2632 & 2632 & 11053 \\
\hline \multirow{2}{*}{$\begin{array}{c}\text { Free } \\
\text { variables }\end{array}$} & $V_{e}$ & 52 & -0.03 & 0.53 & 0.53 & 0.21 \\
\cline { 2 - 7 } & $V_{h}$ & 37 & 0.13 & 0.37 & 0.37 & -0.05 \\
\cline { 2 - 7 } & $Z_{K}$ & 8605263 & -6052.63 & -3947.37 & -3947.37 & -6578.95 \\
\hline
\end{tabular}

According to the values $Z_{N}, Z_{H}, Z_{K}$ in Table 8 , we find the proportions of factorial particles in prices in (11) and (12). In this at initial determination of these proportions the condition is performed: $Z_{K}=0$ - as a free variable:

$$
\begin{aligned}
& 1 * 12000+8 * 11000=100000 \Rightarrow \overline{\mathrm{Z}_{\mathrm{N}}}=12 \% ; \overline{\mathrm{Z}_{\mathrm{H}}}=88 \% ; \\
& 3 * 12000+4 * 11000=80000 \Rightarrow \overline{Z_{N}}=45 \% ; \overline{Z_{H}}=55 \% .
\end{aligned}
$$

In the real structure of service is $Z_{K}>0$ (the proportion of amortization of fixed assets, intangible and material resources in the price of unit of recreational service). Then, according to (10):

$$
\begin{aligned}
& N_{h 1} \cdot z_{N}+H_{h 1} \cdot z_{H}+K_{h 1} \cdot z_{K}=P_{h 1} \Rightarrow \\
& \Rightarrow \overline{Z_{N 1}}+\overline{Z_{H 1}}+\overline{Z_{K 1}}=P_{h 1}=100 \%
\end{aligned} .
$$

In formula 13 we will obtain the adjusted considering the value of $Z_{K}$ proportions of factorial particles in the price of unit of recreational service of certain type. Similarly - for recreational services of other types and in other districts.

According to formula 13, we transfer the actual proportions to the structure of services and get the real value of particles of the land factor in the prices calculated per one service:

$$
\begin{aligned}
& \overline{Z_{N}}+\overline{Z_{H}}+50=100 \Rightarrow 6+44+50=100, \\
& \overline{Z_{N}}+\overline{Z_{H}}+40=80 \Rightarrow 18+22+40=80 .
\end{aligned}
$$

Thus, the share of the land factor in the 1st district is 6 euro - at a price of 100 euro per unit of health care services; 18 euro - at a price of euro 80 per unit of sports type services. 
Weighted average value of share of land factor for the 1st district in calculated per one averaged recreational service (taking into account all types of services that are not included in the basis, i.e. their production expedient for the district):

$\overline{Z_{N 1}}=\frac{\overline{Z_{N 1 h}} \cdot V_{r 1}+\bar{Z}_{N 1 s} \cdot V_{r 2}+\ldots+\overline{Z_{N 1 r}} \cdot V_{r n}}{V_{r 1}+V_{r 2}+\ldots+V_{r n}}$,

where $V_{r l, 2, \ldots, n}$ - the number of recreational services (free variables) of those types which are expedient for production in the district without additional organizational actions.

Similarly, we find the weighted average values of particles of land factor per one averaged recreational service for other districts.

According to formula 14, we find the weighted average value of share of land factor for the 1st district calculated per one averaged recreational service. At the same time as coefficients of weighing acts the number of recreational services: 20000 services of health care type, 60000 services of sports type (Table 8):

$(6 \cdot 20000+18 \cdot 60000) /(20000+60000)=15$ euro.

Similarly, we find the weighted average value of share of land factor for the 2 nd, 3rd and 4th districts. A result we get:

2nd district: 15 euro; 3rd - 18.3 euro; 4th -18.4 euro.

Next we find the closing district with a minimum value of the weighted average value of share of land factor per one averaged recreational service:

$\overline{Z_{N} l}=\min \left\{\overline{Z_{N 1}} ; \overline{Z_{N}} ; \ldots ; \overline{Z_{N}}\right\}$,

where $m$ - the number of districts.

$R R R_{1}=\overline{Z_{N}}-\overline{Z_{N} c l}$,

where $R R R_{1}$ - the regional recreation rent of 1 st district.

Similarly calculate the value of RRR for all other districts within a particular territory.

We find the total value of the regional recreational rent for the 1st district $\left(R R R_{S 1}\right)$ :

$R R R_{S 1}=R R R_{1} \cdot \sum_{i=1}^{n} V_{r i} \cdot$

Similarly, we calculate the total value of RRR for all other districts within a particular territory.

According to formulas, 15-17 the district with the lowest magnitude of share of land factor is closing district. In our case it is the 1 st and 2 nd districts with a share of 15 euro. In the $3 \mathrm{rd}$ and 4th districts we obtain the RRR at the level of $18.3-15=3.3$ (euro/service) and $18.4-15=3.4$ (euro/service), respectively. Aggregate RRR is the multiplication of RRR calculated per one service to the number of services in district (Table 12).

Table 12. The structure of recreational services and regional recreational rent in some districts of Sumy oblast

\begin{tabular}{|c|c|c|c|c|}
\hline \multicolumn{1}{|c|}{ Indicator } & 1st district & 2nd district & 3rd district & 4th district \\
\hline $\begin{array}{c}\text { The number of recreational services within a year: } \\
>\quad \text { of health care type }\end{array}$ & 20000 & 24000 & 27000 & 37000 \\
\hline$>$ of rest houses type & - & 72000 & 51000 & - \\
\hline$>$ of sports type & 60000 & - & - & - \\
\hline$>$ of ecological type & - & - & - & 52000 \\
\hline Regional recreational rent, euro/service & 0 & 0 & 3.3 & 3.4 \\
\hline Aggregate regional recreational rent, thousands euro & 0 & 0 & 257.4 & 302.6 \\
\hline
\end{tabular}

By comparing the total values of RRR in different districts is determined most attractive district for investment (in which the RRR has a maximum value $-R R R_{i n v}$ ) for the development of recreational activity in it:

$R R R_{i n v}=\max \left\{R R R_{1} ; R R R_{2} ; \ldots ; R R R_{m}\right\}$. 
As a result of comparison of all districts we obtain an overall picture of investment attractiveness, which has NRP.

Consequently, the presented approach is based on economic meaning of RRR, which lies in the fact that the structure of recreational services of specified district is more optimal compared with other districts of the district that achieved through more effective organization of recreational activity in the district. According to this the main directions of RRR use are:

1. optimization of the structure of recreational services (formation of structure of recreation economy) in the region;

2. optimization of structure of investments in the recreational sphere of the region by identifying more promising, investment attractive regions;

3. increasing competition between the regions during formation of and provision of recreational services to the population;

4. creation of new jobs in the region;

5. the overall development of recreational sector and the region in a whole, to the market direction taking into account social and ecological interests.

Within the one region economic importance of recreational rent lies in the fact that some of recreational companies use higher quality recreational land in comparison with other companies, and therefore receive additional income, which is the basis for the differential (of the first and of the second kind) recreational rent. In a basis of use of given recreational rent should be laid its targeted reinvestment in reconstitution of recreational resources of the region and complex development of its natural-recreational potential.

According to the formula 18 comparing the received values of RRR, it can be concluded about the existence of advantage in opportunity to obtain greater rent effects in districts with higher value of PPP (results is presented in Table 17 below). We proceed to analysis of the nature of the influence of change of parameters in accord with formulas 5 and 6 in keeping with methodical provisions of the application optimization model of dual assessments at use of NRP of the territory:

1. Analysis of the limits of constancy of prices on recreational services that was not included in the basic plan for the development of recreation in the district (analysis of changes in coefficients of the objective function $L$ with free variables $\Delta P$ ). From the results of the conducted complex assessment of NRP of the territory (Table 5) is evident that the free variables (volumes of recreational services of relevant types) $-X_{r}$ and $X_{e}$. Hence, we will examine the changes of coefficients (prices on service) $P_{r}=70$ euro and $P_{e}=60$ euro (according to the first equation of the system of equations 8 ). Consider the economically acceptable limits of changes of the coefficient $P_{r}$.

Provide the objective function

$L=100 \cdot x_{h}+70 \cdot x_{r}+80 \cdot x_{s}+60 \cdot x_{e} \rightarrow \max$

with increment

$L^{\prime}=100 \cdot x_{h}+\left(70+\Delta P_{r}\right) \cdot x_{r}+80 \cdot x_{s}+60 \cdot x_{e} \rightarrow \max$.

Then in Table 3 will get $70+\Delta P_{r}$ instead of 70 .

As a result of solving of given form we will obtain on the final iteration (according to Table 5) the following form - Table 13.

Table 13. Change in the price on recreational services in rest houses according to the final iteration of complex assessment of NRP of the territory

\begin{tabular}{|c|c|c|c|c|c|}
\hline \multirow{2}{*}{$\begin{array}{c}\text { The baseline } \\
\text { variables }\end{array}$} & Free parameter & \multicolumn{4}{|c|}{ Free variables } \\
\cline { 3 - 6 } & & $Y_{H}$ & $X_{r}$ & $Y_{N}$ & $X_{e}$ \\
\hline$L$ & 6800000 & 11000 & 10000 & 12000 & $22000-\Delta P_{r}$ \\
\hline$X_{s}$ & 60 & -0.05 & 1 & 0.4 & 1.9 \\
\hline$X_{h}$ & 20 & 0.15 & 0 & -0.2 & -0.7 \\
\hline$Y_{K}$ & 3600000 & -6250 & -5000 & -6000 & -11000 \\
\hline
\end{tabular}


From Table 13 evident that the only change that is caused by the transition from $70+\Delta P_{r}$ to $\Delta P_{r}$ is the change of coefficient in row of the objective function in the column $X_{e}$, which is an additional dual assessment of $V_{e}$ (Table 8). That is for the $70+\Delta P_{r}$ and the corresponding optimum value of $V_{e}{ }^{*}=22000$ change occurs $V_{e}^{* *}=22000-\Delta P_{r}$.

The economic importance of additional dual assessment is to explain none expediency of provision of recreational services of relevant type.

Thus $V_{e}{ }^{*}=10000$ means that the marginal cost on production of service of the ecological type of recreation exceed the price of a given service 10000/1000 $=10$ euro.

On the basis of optimality the value of the objective function will be optimal at

$$
\begin{aligned}
& 22000-\Delta P_{r} \geq 0 \Rightarrow \Delta P_{r} \leq 22000 \\
& V_{r}^{*}=22000 \Rightarrow \max \Delta P_{r}=V_{r}^{*}=22000
\end{aligned}
$$

Since the $X_{e}$ is not included in the optimal solution (NRP of the territory), the $\Delta P_{r}$ can be arbitrarily small, i.e. $\min \Delta P_{r}=-\infty$.

Then the limits of change $\Delta P_{r}:-\infty<\Delta P_{r} \leq 22000$.

We proceed from $\Delta P_{r}$ to $P_{r}$ :

$\min P_{r}=P_{r}+\min \Delta P_{r}$;

$\max P_{r}=P_{r}+\max \Delta P_{r}$;

$\min P_{r} \leq P_{r} \leq \max P_{r}$.

Since the negative value of $P_{r}$, which means the price of recreational service is meaningless, then min $P_{r}=\mathrm{O}$ and the limits of change $P_{r}$ will look like:

$0 \leq P_{r} \leq \max P_{r}$

$0 \leq P_{r} \leq P_{r}+V_{r}^{*}$.

In our case calculated per one service $P_{r}=70$ euro, $V_{e}{ }^{*}=22$ euro.

Then the limits of change will be equal to: $0 \leq P_{r} \leq 92$.

That is the changes of $P_{r}$ in these limits leads only to change of $V_{r}$ :

$V_{r}^{* * *}=V_{r}^{*}-\Delta P_{r}$.

All the latest characteristics of optimal solution remain unchanged.

Similarly to the above algorithm were determined the limits of sustainability for the price of recreational services of ecological type: $0 \leq P_{e} \leq 70$.

2. Analysis of the limits of sustainability of prices on recreational services that was included in the baseline plan of development of recreation in the district (analysis of changes in the coefficients of the objective function $L$ at baseline variables $\Delta P$ ).

From Table 5 is evident that the basic variables (volumes of recreational services of health care and sports recreation) $-X_{h}$ and $X_{s}$. Hence, we are going to examine change of coefficients (the prices on services) $P_{h}=100$ euro and $P_{s}=80$ euro (according to the first equation of the system of equations 8 ). Consider the economically acceptable limits of change of coefficient $P_{h}$.

Provide the objective function

$L=100 \cdot x_{h}+70 \cdot x_{r}+80 \cdot x_{s}+60 \cdot x_{e} \rightarrow \max$

with increment

$L^{\prime}=\left(100+\Delta P_{h}\right) \cdot x_{h}+70 \cdot x_{r}+80 \cdot x_{s}+60 \cdot x_{e} \rightarrow \max$.

Then will get $100+\Delta P_{h}$ instead of 100 in Table 3 . 
As a result of solving of given form we will obtain on the final iteration (according to Table 5) the following form - Table 14.

Table 14. Change in the price on service of health care recreation according to the final iteration of complex assessment of NRP of the territory

\begin{tabular}{|c|c|c|c|c|c|}
\hline \multirow{2}{*}{$\begin{array}{c}\text { The baseline } \\
\text { variables }\end{array}$} & \multirow{2}{*}{ Free parameter } & \multicolumn{4}{|c|}{ Free variables } \\
\cline { 3 - 6 } & & $Y_{H}$ & $X_{r}$ & $Y_{N}$ & $X_{e}$ \\
\hline \multirow{2}{*}{$L$} & $\begin{array}{c}6800000+ \\
+20 \Delta P_{h}\end{array}$ & $\begin{array}{c}11000+ \\
+0,15 \Delta P_{h}\end{array}$ & 10000 & $12000-$ & $22000-$ \\
& 60 & -0.05 & 1 & $-0,2 \Delta P_{h}$ & $\Delta P_{h}$ \\
\hline$X_{s}$ & 20 & 0.15 & 0 & -0.2 & -4 \\
\hline$X_{h}$ & 3600000 & -6250 & -5000 & -6000 & -11000 \\
\hline$Y_{K}$ & & & & \\
\hline
\end{tabular}

We get the system of inequalities:

$$
\left\{\begin{array} { l } 
{ 1 1 0 0 0 + 0 . 1 5 \Delta P _ { h } \geq 0 } \\
{ 1 2 0 0 0 - 0 . 2 \Delta P _ { h } \geq 0 } \\
{ 2 2 0 0 0 - 0 . 7 \Delta P _ { h } \geq 0 }
\end{array} \Rightarrow \left\{\begin{array}{l}
\Delta P_{h} \geq-73333 \\
\Delta P_{h} \leq 60000 \\
\Delta P_{h} \leq 31429
\end{array} \Rightarrow-73333 \leq \Delta P_{h} \leq 31429 .\right.\right.
$$

Hence calculated per one service:

$\left\{\begin{array}{l}\min \Delta P_{h}=-73.3 \\ \max \Delta P_{h}=31.4\end{array} \Rightarrow\left\{\begin{array}{l}\min P_{h}=P_{h}+\min \Delta P_{h} \\ \max P_{h}=P_{h}+\max \Delta P_{h}\end{array} \Rightarrow 26.7 \leq P_{h} \leq 131.4\right.\right.$.

Given that it is forecasted the positive trend of change in prices for recreational services, then according to the initial price on the service of health care recreation:

$100 \leq P_{h} \leq 131.4$.

When changing the $P_{h}$ in the defined limits are kept the structure of recreational services that provided in the district. The row of objective function is changing - in our case:

1. The value of NRP is changing by the equation $L^{* *}=L^{*}+20 \odot \Delta P_{h}$ :

$5333340 \leq L^{* *} \leq 12761920$;

2. Factorial proportions of marginal prices on recreational land and human resources are changing (calculated per one service), respectively:

$$
\left\{\begin{array} { c } 
{ \mathrm { Z } _ { \mathrm { N } } ^ { * * } = \mathrm { Z } _ { \mathrm { N } } ^ { * } - 0 . 2 \Delta P _ { h } } \\
{ \mathrm { Z } _ { \mathrm { H } } ^ { * * } = \mathrm { Z } _ { \mathrm { H } } ^ { * } + 0 . 1 5 \Delta P _ { h } }
\end{array} \Rightarrow \left\{\begin{array}{l}
0 \leq \mathrm{Z}_{\mathrm{N}}^{* *} \leq 26.7 \\
0 \leq \mathrm{Z}_{\mathrm{H}}^{* *} \leq 15.7
\end{array}\right.\right. \text {. }
$$

Similarly to the above algorithm were determined the limits of sustainability for the price of recreational services of sports type:

$$
\left\{\begin{array} { l } 
{ 1 1 0 0 0 - 0 . 0 5 \Delta P _ { s } \geq 0 } \\
{ 1 0 0 0 0 + \Delta P _ { s } \geq 0 } \\
{ 1 2 0 0 0 + 0 . 4 \Delta P _ { s } \geq 0 } \\
{ 2 2 0 0 0 + 1 . 9 \Delta P _ { s } \geq 0 }
\end{array} \Rightarrow \left\{\begin{array}{l}
\Delta P_{s} \leq 220000 \\
\Delta P_{s} \geq-10000 \\
\Delta P_{s} \geq-30000 \\
\Delta P_{s} \geq-11579
\end{array} \Rightarrow-10000 \leq \Delta P_{s} \leq 220000 ;\right.\right.
$$

calculated per one service:

$$
\begin{aligned}
& \left\{\begin{array} { l } 
{ \operatorname { m i n } \Delta P _ { s } = - 1 0 } \\
{ \operatorname { m a x } \Delta P _ { s } = 2 2 0 }
\end{array} \Rightarrow \left\{\begin{array}{l}
\min P_{s}=P_{s}+\min \Delta P_{s} \\
\max P_{s}=P_{s}+\max \Delta P_{s}
\end{array} \Rightarrow 70 \leq P_{s} \leq 300\right.\right. \\
& L^{* *}=L^{*}+60 \odot \Delta P_{h} ; \\
& 6200000 \leq L^{* *} \leq 20000000 .
\end{aligned}
$$




$$
\left\{\begin{array} { l } 
{ \mathrm { Z } _ { \mathrm { N } } ^ { * * } = \mathrm { Z } _ { \mathrm { N } } ^ { * } + 0 . 4 \Delta P _ { s } } \\
{ \mathrm { Z } _ { \mathrm { H } } ^ { * * } = \mathrm { Z } _ { \mathrm { H } } ^ { * } - 0 . 0 5 \Delta P _ { s } }
\end{array} \Rightarrow \left\{\begin{array}{l}
8 \leq \mathrm{Z}_{\mathrm{N}}^{* *} \leq 1000 \\
0 \leq \mathrm{Z}_{\mathrm{H}}^{* *} \leq 11.5
\end{array}\right.\right. \text {. }
$$

3. Analysis of limitations on recreational resources on which reserve is absent within the defined territory.

The results of the final iteration of complex assessment of NRP of the territory in Table 5 indicate that the reserve on recreational lands $(N=200$ hectares) and human recreational resources $(H=400$ persons $)$ is absent. Consider the change of area recreational lands. We change the $N$ to $\Delta N$ according to formula 6 . In this limitation on recreational lands becomes:

$x_{h}+3 \cdot x_{r}+3 \cdot x_{s}+5 \cdot x_{e} \leq 200+\Delta N$.

After reduction to standard form:

$Y_{N}=(200+\Delta N)-\left(x_{h}+3 \cdot x_{r}+3 \cdot x_{s}+5 \cdot x_{e}\right)$.

As a result, of search of optimal solution (Table 15) we get:

Table 15. Change in limitations on recreational land according to the final iteration of complex assessment of NRP of the territory

\begin{tabular}{|c|l|c|c|c|c|}
\hline \multirow{2}{*}{$\begin{array}{c}\text { The baseline } \\
\text { variables }\end{array}$} & \multirow{2}{*}{ Free parameter } & \multicolumn{4}{|c|}{ Free variables } \\
\cline { 3 - 5 } & & $Y_{H}$ & $X_{r}$ & $Y_{N}$ & $X_{e}$ \\
\hline$L$ & $6800000+12000 \odot \Delta N$ & 11000 & 10000 & 12000 & 22000 \\
\hline$X_{s}$ & $60+0,4 \odot \Delta N$ & -0.05 & 1 & 0.4 & 1.9 \\
\hline$X_{h}$ & $20-0,2 \odot \Delta N$ & 0.15 & 0 & -0.2 & -0.7 \\
\hline$Y_{K}$ & $3600000-6000 \odot \Delta N$ & -6250 & -5000 & -6000 & -11000 \\
\hline
\end{tabular}

$$
\begin{aligned}
& \left\{\begin{array} { l } 
{ 6 0 + 0 . 4 \Delta N \geq 0 } \\
{ 2 0 - 0 . 2 \Delta N \geq 0 } \\
{ 3 6 0 0 0 0 0 - 6 0 0 0 \Delta N \geq 0 }
\end{array} \Rightarrow \left\{\begin{array}{l}
\Delta N \geq-150 \\
\Delta N \leq 100 \\
\Delta N \leq 600
\end{array} \Rightarrow-150 \leq \Delta N \leq 100\right.\right.
\end{aligned}
$$

Change of areas of recreational lands within certain limits will not violate the structure of the recreational services that provided in the district. However, the value of NRP of the territory will change (1) and the number of services on the types of recreational activity in the district (2):

1) $L^{* *}=L^{*}+12000 \Delta N$ :

$5000000 \leq L^{* *} \leq 8000000 ;$

2) $\left\{\begin{array}{l}X_{h}^{* *}=X_{h}^{*}-0.2 \cdot \Delta N \\ X_{s}^{* *}=X_{s}^{*}+0.4 \cdot \Delta N\end{array} \Rightarrow\left\{\begin{array}{c}0 \leq X_{h}^{* *} \leq 5000 \\ 0 \leq X_{s}^{* *} \leq 10000\end{array}\right.\right.$.

Similarly to the above algorithm were determined the limits of sustainability for constraints on human resources:

$$
\begin{aligned}
& \left\{\begin{array} { l } 
{ 6 0 - 0 . 0 5 \Delta H \geq 0 } \\
{ 2 0 + 0 . 1 5 \Delta H \geq 0 } \\
{ 3 6 0 0 0 0 0 - 6 2 5 0 \Delta H \geq 0 }
\end{array} \Rightarrow \left\{\begin{array}{l}
\Delta H \leq 1200 \\
\Delta H \geq-133 \\
\Delta H \leq 576
\end{array} \Rightarrow-133 \leq \Delta H \leq 576 ;\right.\right.
\end{aligned}
$$


$5337000 \leq L^{* *} \leq 13136000 ;$

2) $\left\{\begin{array}{l}X_{h}^{* * *}=X_{h}^{*}+0.15 \cdot \Delta H \\ X_{s}^{* * *}=X_{s}^{*}-0.05 \cdot \Delta H\end{array} \Rightarrow\left\{\begin{array}{c}0 \leq X_{h}^{* *} \leq 10640 \\ 3120 \leq X_{s}^{* * *} \leq 6665\end{array}\right.\right.$.

4. Analysis of limitations on recreational resources on which are the reserve within the defined territory.

The results of the final iteration of complex assessment of NRP of the territory in Table 5 indicate that there is a reserve on financial recreational resources ( $K=7000000$ euro). Consider the change of financial recreational resources. We change the $K$ to $\Delta K$ (according to Formula 6). In this limitation on recreational lands becomes:

$50 \cdot x_{h}+35 \cdot x_{r}+40 \cdot x_{s}+30 \cdot x_{e} \leq 7000000+\Delta K$.

After reduction to standard form:

$Y_{K}=(7000000+\Delta K)-\left(50 \cdot x_{h}+35 \cdot x_{r}+40 \cdot x_{s}+30 \cdot x_{e}\right)$.

As a result, of search of optimal solution (Table 16) we get: with compliance the initial conditions of investment, i.e. positive tendency of change of financial investments $(\Delta K \geq 0)$ and setting the upper limit of investment $(K \leq 7000000)$ :

$\left\{\begin{array}{l}\min K=K+\min \Delta K \\ \max K=K+\max \Delta K\end{array} \Rightarrow \min K \leq K \leq \max K \Rightarrow 3600000 \leq K \leq 7000000\right.$.

Table 16. Change in limitations on financial recreational resources according to the final iteration of complex assessment of NRP of the territory

\begin{tabular}{|c|c|c|c|c|c|}
\hline \multirow{2}{*}{$\begin{array}{c}\text { The baseline } \\
\text { variables }\end{array}$} & \multirow{2}{*}{ Free parameter } & \multicolumn{4}{|c|}{ Free variables } \\
\cline { 3 - 6 } & & $Y_{H}$ & $X_{r}$ & $Y_{N}$ & $X_{e}$ \\
\hline$L$ & 6800000 & 11000 & 10000 & 12000 & 22000 \\
\hline$X_{s}$ & 60 & -0.05 & 1 & 0.4 & 1.9 \\
\hline$X_{h}$ & 20 & 0.15 & 0 & -0.2 & -0.7 \\
\hline$Y_{K}$ & $3600000+\Delta K$ & -6250 & -5000 & -6000 & -11000 \\
\hline
\end{tabular}

Change in financial resources within certain limits will not affect the value of the objective function (NRP of the territory) and the structure and amount of recreational services in the district. The only value that changes is the reserve on financial recreational resources. The main results of conducted research on the example of NRP of Sumy oblast are set out in Tables 17-23.

Table 17. The investment attractiveness of districts of Sumy oblast from the perspective of development of recreational activity

\begin{tabular}{|c|c|c|c|c|c|}
\hline District & $\begin{array}{l}\text { Indicator of } \\
\text { attractiveness } \\
\left(\overline{Z_{N(1)}}\right)\end{array}$ & $\begin{array}{l}\text { Rating } \\
\text { (from I } \\
\text { to III) }\end{array}$ & District & $\begin{array}{l}\text { Indicator of } \\
\text { attractiveness } \\
\left(\overline{Z_{N(1)}}\right)\end{array}$ & $\begin{array}{l}\text { Rating } \\
\text { (from I } \\
\text { to III) }\end{array}$ \\
\hline Bilopilskyy & 5.5 & III & Nedryhaylivskyy & 10.4 & II \\
\hline Burynskyy & 6.9 & III & Okhtyrskyy & 14.6 & $\mathrm{I}$ \\
\hline Velykopusarivskyy & 12.3 & II & Putyvlskyy & 15.7 & $\mathrm{I}$ \\
\hline Hlukhivskyy & 13.4 & $\mathrm{I}$ & Romenskyy & 12.5 & $\mathrm{I}$ \\
\hline Konotopskyy & 10.8 & II & Seredynobudskyy & 9.0 & III \\
\hline Krasnopilskyy & 9.3 & III & Sumskyy & 14.5 & $\mathrm{I}$ \\
\hline Krolevetskyy & 11.2 & II & Trostianetskyy & 13.0 & $\mathrm{I}$ \\
\hline Lebedynskyy & 15.9 & $\mathrm{I}$ & Shostkynskyy & 10.1 & II \\
\hline Lypovodolynskyy & 7.8 & III & Yampilskyy & 6.7 & III \\
\hline
\end{tabular}


Table 18. Investments in development of recreational activity by type of recreational services by districts of Sumy oblast

\begin{tabular}{|l|l|c|l|l|c|}
\hline \multicolumn{1}{|c|}{ District } & $\begin{array}{c}\text { Types of recreational } \\
\text { activity }\end{array}$ & $\begin{array}{c}\text { Investments, } \\
\text { ths. euro }\end{array}$ & \multicolumn{1}{|c|}{ District } & \multicolumn{1}{c|}{$\begin{array}{c}\text { Types of } \\
\text { recreational activity }\end{array}$} & $\begin{array}{c}\text { Investments, } \\
\text { ths. euro }\end{array}$ \\
\hline Bilopilskyy & health care sports & 3400 & Nedryhaylivskyy & health care sports & 4147 \\
\hline Burynskyy & health care rest houses & 3645 & Okhtyrskyy & health care rest houses & 4680 \\
\hline Velykopusarivskyy & health care ecological & 4027 & Putyvlskyy & health care ecological & 4132 \\
\hline Hlukhivskyy & health care ecological & 4106 & Romenskyy & health care rest houses & 4115 \\
\hline Konotopskyy & health care sports & 4442 & Seredynobudskyy & sports ecological & 3853 \\
\hline Krasnopilskyy & health care sports & 3580 & Sumskyy & rest houses ecological & 5635 \\
\hline Krolevetskyy & health care rest houses & 4081 & Trostianetskyy & health care rest houses & 3637 \\
\hline Lebedynskyy & health care sports & 5114 & Shostkynskyy & health care rest houses & 4819 \\
\hline Lypovodolynskyy & sports ecological & 2974 & Yampilskyy & health care rest houses & 4120 \\
\hline
\end{tabular}

Table 19. Absolute values and limits of change (caused by price dynamics on recreational services) of values for local NRP on districts of Sumy oblast

\begin{tabular}{|l|c|c|c|l|c|c|c|}
\hline \multicolumn{1}{|c|}{ District } & $\begin{array}{c}\text { NRP, } \\
\text { ths. } \\
\text { euro }\end{array}$ & $\begin{array}{c}\text { NRP }- \\
\Delta \text { NRP, } \\
\text { ths. euro }\end{array}$ & $\begin{array}{c}\text { NRP }+ \\
\Delta \text { NRP, } \\
\text { ths. euro }\end{array}$ & \multicolumn{1}{|c|}{ District } & $\begin{array}{c}\text { NRP, ths. } \\
\text { euro }\end{array}$ & $\begin{array}{c}\text { NRP }- \\
\Delta \text { NRP, } \\
\text { ths. euro }\end{array}$ & $\begin{array}{c}\text { NRP }+ \\
\Delta \text { NRP, } \\
\text { ths. euro }\end{array}$ \\
\hline Bilopilskyy & 6800 & 5980 & 7615 & Nedryhaylivskyy & 8295 & 4330 & 12660 \\
\hline Burynskyy & 7290 & 5609 & 10089 & Okhtyrskyy & 9360 & 6090 & 13440 \\
\hline Velykopusarivskyy & 8053 & 3880 & 11230 & Putyvlskyy & 8263 & 6005 & 11380 \\
\hline Hlukhivskyy & 8211 & 6554 & 10950 & Romenskyy & 8230 & 5670 & 12770 \\
\hline Konotopskyy & 8884 & 4980 & 11090 & Seredynobudskyy & 7706 & 3680 & 10095 \\
\hline Krasnopilskyy & 7159 & 4320 & 9980 & Sumskyy & 11271 & 7990 & 14640 \\
\hline Krolevetskyy & 8192 & 4890 & 11240 & Trostianetskyy & 7273 & 4780 & 11440 \\
\hline Lebedynskyy & 10228 & 7460 & 14070 & Shostkynskyy & 9637 & 5580 & 12030 \\
\hline Lypovodolynskyy & 7947 & 4440 & 9550 & Yampilskyy & 8240 & 4225 & 10035 \\
\hline
\end{tabular}

Table 20. Dynamics of prices on recreational services of certain types while maintaining the structure of NRP of the territory

\begin{tabular}{|c|c|c|c|c|c|c|c|}
\hline \multirow{2}{*}{ District } & \multirow{2}{*}{$\begin{array}{l}\text { Type of } \\
\text { service }\end{array}$} & \multicolumn{2}{|c|}{ Price, euro } & \multirow{2}{*}{ District } & \multirow{2}{*}{$\begin{array}{l}\text { Type of } \\
\text { service }\end{array}$} & \multicolumn{2}{|c|}{ Price, euro } \\
\hline & & $\min$ & $\max$ & & & $\min$ & $\max$ \\
\hline Bilopilskyy & $\begin{array}{c}\text { health care } \\
\text { sports }\end{array}$ & $\begin{array}{c}1000 \\
800\end{array}$ & $\begin{array}{l}1320 \\
1210\end{array}$ & Nedryhaylivskyy & $\begin{array}{l}\text { health care } \\
\text { sports }\end{array}$ & $\begin{array}{c}1050 \\
800\end{array}$ & $\begin{array}{l}1275 \\
1005\end{array}$ \\
\hline Burynskyy & $\begin{array}{l}\text { health care } \\
\text { rest houses }\end{array}$ & $\begin{array}{c}1000 \\
900\end{array}$ & $\begin{array}{l}1220 \\
1050\end{array}$ & Okhtyrskyy & $\begin{array}{l}\text { health care } \\
\text { rest houses }\end{array}$ & 1200900 & $\begin{array}{l}1340 \\
1105\end{array}$ \\
\hline Velykopusarivskyy & $\begin{array}{l}\text { health care } \\
\text { ecological }\end{array}$ & $\begin{array}{c}1100 \\
700\end{array}$ & $\begin{array}{c}1325 \\
970\end{array}$ & Putyvlskyy & $\begin{array}{l}\text { health care } \\
\text { ecological }\end{array}$ & $\begin{array}{c}1100 \\
800\end{array}$ & $\begin{array}{l}1290 \\
1030\end{array}$ \\
\hline Hlukhivskyy & $\begin{array}{l}\text { health care } \\
\text { ecological }\end{array}$ & $\begin{array}{c}1180 \\
870 \\
\end{array}$ & $\begin{array}{l}1490 \\
1300 \\
\end{array}$ & Romenskyy & $\begin{array}{l}\text { health care } \\
\text { rest houses }\end{array}$ & $\begin{array}{c}1220 \\
880 \\
\end{array}$ & $\begin{array}{l}1490 \\
1100 \\
\end{array}$ \\
\hline Konotopskyy & $\begin{array}{c}\text { health care } \\
\text { sports }\end{array}$ & $\begin{array}{c}1100 \\
980\end{array}$ & $\begin{array}{l}1410 \\
1155\end{array}$ & Seredynobudskyy & $\begin{array}{c}\text { sports } \\
\text { ecological }\end{array}$ & $\begin{array}{l}840 \\
780\end{array}$ & $\begin{array}{c}1040 \\
905\end{array}$ \\
\hline Krasnopilskyy & $\begin{array}{c}\text { health care } \\
\text { sports }\end{array}$ & $\begin{array}{l}970 \\
800 \\
\end{array}$ & $\begin{array}{l}1205 \\
1080 \\
\end{array}$ & Sumskyy & $\begin{array}{l}\text { rest houses } \\
\text { ecological }\end{array}$ & $\begin{array}{c}1220 \\
800 \\
\end{array}$ & $\begin{array}{l}1560 \\
1350 \\
\end{array}$ \\
\hline Krolevetskyy & $\begin{array}{l}\text { health care } \\
\text { rest houses }\end{array}$ & $\begin{array}{c}1190 \\
900\end{array}$ & $\begin{array}{l}1410 \\
1170\end{array}$ & Trostianetskyy & $\begin{array}{l}\text { health care } \\
\text { rest houses }\end{array}$ & $\begin{array}{c}1040 \\
870\end{array}$ & $\begin{array}{l}1200 \\
1100\end{array}$ \\
\hline Lebedynskyy & $\begin{array}{c}\text { health care } \\
\text { sports }\end{array}$ & $\begin{array}{c}950 \\
1000\end{array}$ & $\begin{array}{l}1320 \\
1200\end{array}$ & Shostkynskyy & $\begin{array}{l}\text { health care } \\
\text { rest houses }\end{array}$ & $\begin{array}{l}900 \\
910\end{array}$ & $\begin{array}{l}1270 \\
1235\end{array}$ \\
\hline Lypovodolynskyy & $\begin{array}{c}\text { sports } \\
\text { ecological }\end{array}$ & $\begin{array}{l}780 \\
800\end{array}$ & $\begin{array}{l}975 \\
940\end{array}$ & Yampilskyy & $\begin{array}{l}\text { health care } \\
\text { rest houses }\end{array}$ & $\begin{array}{c}1160 \\
880\end{array}$ & $\begin{array}{c}1340 \\
990\end{array}$ \\
\hline
\end{tabular}


Table 21. Volumes and upper limit of forecasted increase of recreational services by districts of Sumy oblast

\begin{tabular}{|c|c|c|c|c|c|c|c|}
\hline District & $\begin{array}{l}\text { Type of } \\
\text { service }\end{array}$ & $\begin{array}{l}\text { Volume } \\
\text { of } \\
\text { services, } \\
\text { units }\end{array}$ & $\begin{array}{c}\text { Volume } \\
+ \\
\max \Delta \\
\text { units }\end{array}$ & District & $\begin{array}{l}\text { Type of } \\
\text { service }\end{array}$ & $\begin{array}{l}\text { Volume } \\
\text { of } \\
\text { services, } \\
\text { units }\end{array}$ & $\begin{array}{c}\text { Volume } \\
+ \\
\max \Delta, \\
\text { units }\end{array}$ \\
\hline Bilopilskyy & $\begin{array}{c}\text { health care } \\
\text { sports }\end{array}$ & $\begin{array}{l}20000 \\
60000 \\
\end{array}$ & $\begin{array}{l}37000 \\
85000 \\
\end{array}$ & Nedryhaylivskyy & $\begin{array}{c}\text { health care } \\
\text { sports }\end{array}$ & $\begin{array}{l}31000 \\
63000 \\
\end{array}$ & $\begin{array}{l}42800 \\
80100 \\
\end{array}$ \\
\hline Burynskyy & $\begin{array}{l}\text { health care } \\
\text { rest houses }\end{array}$ & $\begin{array}{l}27000 \\
51000 \\
\end{array}$ & $\begin{array}{l}30700 \\
67900 \\
\end{array}$ & Okhtyrskyy & $\begin{array}{l}\text { health care } \\
\text { rest houses }\end{array}$ & $\begin{array}{l}24000 \\
72000 \\
\end{array}$ & $\begin{array}{l}30100 \\
80500 \\
\end{array}$ \\
\hline $\begin{array}{l}\text { Velyko- } \\
\text { pusarivskyy }\end{array}$ & $\begin{array}{l}\text { health care } \\
\text { ecological }\end{array}$ & $\begin{array}{l}57630 \\
24470\end{array}$ & $\begin{array}{l}80550 \\
29750\end{array}$ & Putyvlskyy & $\begin{array}{l}\text { health care } \\
\text { ecological }\end{array}$ & $\begin{array}{l}36840 \\
52630\end{array}$ & $\begin{array}{l}43000 \\
73000\end{array}$ \\
\hline Hlukhivskyy & $\begin{array}{l}\text { health care } \\
\text { ecological }\end{array}$ & $\begin{array}{l}41840 \\
37630\end{array}$ & $\begin{array}{l}65750 \\
67100 \\
\end{array}$ & Romenskyy & $\begin{array}{l}\text { health care } \\
\text { rest houses }\end{array}$ & $\begin{array}{l}35000 \\
45000\end{array}$ & $\begin{array}{l}43600 \\
87000\end{array}$ \\
\hline Konotopskyy & $\begin{array}{c}\text { health care } \\
\text { sports }\end{array}$ & $\begin{array}{l}13500 \\
75500\end{array}$ & $\begin{array}{l}19000 \\
86000\end{array}$ & Seredyno-budskyy & $\begin{array}{c}\text { sports ecologi- } \\
\text { cal }\end{array}$ & $\begin{array}{l}77140 \\
15710\end{array}$ & $\begin{array}{c}105450 \\
20700\end{array}$ \\
\hline Krasnopilskyy & $\begin{array}{c}\text { health care } \\
\text { sports }\end{array}$ & $\begin{array}{l}7000 \\
81000\end{array}$ & $\begin{array}{c}15300 \\
120500\end{array}$ & Sumskyy & $\begin{array}{l}\text { rest houses } \\
\text { ecological }\end{array}$ & $\begin{array}{c}112140 \\
710\end{array}$ & $\begin{array}{c}130700 \\
2600\end{array}$ \\
\hline Krolevetskyy & $\begin{array}{l}\text { health care } \\
\text { rest houses }\end{array}$ & $\begin{array}{l}28000 \\
54000\end{array}$ & $\begin{array}{l}34500 \\
72400\end{array}$ & Trostianetskyy & $\begin{array}{l}\text { health care } \\
\text { rest houses }\end{array}$ & $\begin{array}{l}23500 \\
55500\end{array}$ & $\begin{array}{l}34500 \\
90700\end{array}$ \\
\hline Lebedynskyy & $\begin{array}{l}\text { health care } \\
\text { sports }\end{array}$ & $\begin{array}{l}14500 \\
88500\end{array}$ & $\begin{array}{c}18900 \\
104300\end{array}$ & Shostkynskyy & $\begin{array}{l}\text { health care } \\
\text { rest houses }\end{array}$ & $\begin{array}{c}9000 \\
97000\end{array}$ & $\begin{array}{c}20350 \\
128000\end{array}$ \\
\hline Lypovo-dolynskyy & $\begin{array}{c}\text { sports } \\
\text { ecological }\end{array}$ & $\begin{array}{l}83570 \\
17860\end{array}$ & $\begin{array}{c}114300 \\
24000\end{array}$ & Yampilskyy & $\begin{array}{l}\text { health care } \\
\text { rest houses }\end{array}$ & $\begin{array}{l}24000 \\
62000\end{array}$ & $\begin{array}{l}35700 \\
90700\end{array}$ \\
\hline
\end{tabular}

Table 22. Limits of sustainability for limitations on land resources and conditioned by them changes of value of local NRP by districts of Sumy oblast

\begin{tabular}{|l|c|c|c|c|}
\hline \multirow{2}{*}{ District } & \multicolumn{2}{|c|}{ Area of recreational lands } & NRP $-\Delta$ NRP, thou- & \multirow{2}{*}{$\begin{array}{c}\text { NRP }+\Delta \text { NRP, } \\
\text { thousands euro }\end{array}$} \\
\cline { 2 - 3 } & $-\max \Delta$, hectares & $+\max \Delta$, hectares & 5960 & 7605 \\
\hline Bilopilskyy & 170 & 230 & 5579 & 10069 \\
\hline Burynskyy & 150 & 210 & 3860 & 11210 \\
\hline Velykopusarivskyy & 150 & 210 & 6534 & 10930 \\
\hline Hlukhivskyy & 200 & 260 & 4960 & 11070 \\
\hline Konotopskyy & 210 & 270 & 4300 & 9950 \\
\hline Krasnopilskyy & 220 & 280 & 4870 & 11210 \\
\hline Krolevetskyy & 160 & 220 & 7440 & 14060 \\
\hline Lebedynskyy & 250 & 310 & 4420 & 9520 \\
\hline Lypovodolynskyy & 310 & 370 & 4310 & 12630 \\
\hline Nedryhaylivskyy & 190 & 250 & 6070 & 13420 \\
\hline Okhtyrskyy & 210 & 270 & 6000 & 11350 \\
\hline Putyvlskyy & 270 & 330 & 5650 & 12750 \\
\hline Romenskyy & 140 & 200 & 3640 & 10055 \\
\hline Seredynobudskyy & 280 & 340 & 7970 & 14620 \\
\hline Sumskyy & 310 & 370 & 4760 & 11410 \\
\hline Trostianetskyy & 160 & 220 & 5560 & 12010 \\
\hline Shostkynskyy & 270 & 330 & 4205 & 10015 \\
\hline Yampilskyy & 180 & 340 & & \\
\hline
\end{tabular}

Table 23. Limits of sustainability for limitations on human resources and conditioned by them changes of value of local NRP by districts of Sumy oblast

\begin{tabular}{|l|c|c|c|c|}
\hline \multirow{2}{*}{ District } & \multicolumn{2}{|c|}{$\begin{array}{c}\text { The number of human resources involved in } \\
\text { recreational activity }\end{array}$} & $\begin{array}{c}\text { NRP }-\Delta \mathrm{NRP}, \\
\text { ths. euro }\end{array}$ & $\begin{array}{c}\text { NRP }+\Delta \mathrm{NRP}, \\
\text { ths. euro }\end{array}$ \\
\cline { 2 - 5 } & $-\max \Delta$, persons & $+\max \Delta$, persons & 5960 & 7635 \\
\hline Bilopilskyy & 370 & 440 & 5600 & 10120 \\
\hline Burynskyy & 400 & 465 & 500 \\
\hline
\end{tabular}


Table 23 (cont.). Limits of sustainability for limitations on human resources and conditioned by them changes of value of local NRP by districts of Sumy oblast

\begin{tabular}{|l|c|c|c|c|}
\hline \multicolumn{1}{|c|}{ District } & \multicolumn{2}{c|}{$\begin{array}{c}\text { The number human resources involved in } \\
\text { recreational activity }\end{array}$} & $\begin{array}{c}\text { NRP }-\Delta \text { NRP, } \\
\text { ths. euro }\end{array}$ & $\begin{array}{c}\text { NRP }+\Delta \text { NRP, } \\
\text { ths. euro }\end{array}$ \\
\hline Velykopusarivskyy & 460 & 550 & 3820 & 11430 \\
\hline Hlukhivskyy & 370 & 430 & 6524 & 10990 \\
\hline Konotopskyy & 380 & 440 & 4960 & 11290 \\
\hline Krasnopilskyy & 350 & 420 & 4300 & 1995 \\
\hline Krolevetskyy & 410 & 475 & 4860 & 1290 \\
\hline Lebedynskyy & 440 & 505 & 7430 & 9590 \\
\hline Lypovodolynskyy & 330 & 385 & 4410 & 12690 \\
\hline Nedryhaylivskyy & 470 & 535 & 4300 & 13540 \\
\hline Okhtyrskyy & 440 & 520 & 6000 & 11490 \\
\hline Putyvlskyy & 360 & 435 & 6000 & 12790 \\
\hline Romenskyy & 420 & 505 & 5650 & 10135 \\
\hline Seredynobudskyy & 310 & 370 & 3650 & 14690 \\
\hline Sumskyy & 520 & 590 & 7970 & 11490 \\
\hline Trostianetskyy & 340 & 455 & 4750 & 12130 \\
\hline Shostkynskyy & 430 & 500 & 5560 & 10080 \\
\hline Yampilskyy & 410 & 495 & 4220 & \\
\hline
\end{tabular}

\section{Conclusions}

As a result of the conducted research the following conclusions can be made. Firstly, a complex economic assessment of natural-recreational potential of Sumy oblast was carried out, the values of regional recreational rent in districts of Sumy oblast was defined. The character of influence of change of parameters of the objective function of maximization of recreational product on the aggregate magnitude and structure of recreational services is analyzed, in accordance with methodical provisions of application the optimization instrument of dual assessments at use of natural-recreational potential of the territory: an analysis of the limits of sustainability of prices on recreational services that are included or not included to the baseline plan of recreational development in districts of oblast; analysis of limitations on recreational resources on which is absent or available reserve within the framework of defined territory.

Secondly, among the main results of conducted complex assessment of natural-recreational potential of Sumy oblast highlighted the following: defined the investment attractiveness of districts of the oblast from the perspective of development in them the recreational activity; determined the volume of investments in development of recreational activity by types of recreational services on districts of oblast; assessed the absolute values and limits of change of local natural-recreational potentials conditioned by the dynamics of prices on recreational services in districts of oblast; researched the dynamics of prices on recreational services of defined types of while maintaining the structure of natural-recreational potential of the oblast; determined the volumes and upper limits of forecasted increase of recreational services on districts of oblast; determined the limitations of sustainability for constraints on land and labor resources and conditioned by them change in the magnitude of local natural-recreational potential on districts of oblast.

Further studies will be focused on the development of models of management of investment recreational resources in the system of the national economy, especially in view of the recreational impact on health of the population.

\section{References}

1. Andkjer, S., Arvidsen, J. (2015). Places for active outdoor recreation - a scoping review. Journal of Outdoor Recreation and Tourism, 12, 25-46. doi:10.1016/j.jort.2015.10.001.

2. Azar, V.I. (1972). Ekonomika i organizatsiya turizma [Economics and organization of tourism]. Moscow, Ekonomika, 184 p.

3. Dehez, J., Lyser, S. (2014). Combining multivariate analysis and cost analysis in outdoor recreation planning. Journal of Outdoor Recreation and Tourism, 7-8, 75-88. doi:10.1016/j.jort.2014.09.002. 
4. Department of Culture and Tourism of Sumy Regional State Administration (2017). Sumshchina turistichna ta kul'turno-mistets'ka [Sumy - tourist and cultural and artistic]. Retrieved from http://sumytour.in.ua/.

5. Ekonomicheskiy potentsial administrativnykh i proizvodstvennykh sistem [The economic potential of administrative and production systems] (2006). ed. Balatsky, O.F. Sumy, PTH "Universitetskaya kniga”, $973 \mathrm{p}$.

6. Department of Statistics in the Sumy Oblast: official site, available at: http://sumy.ukrstat.gov.ua/.

7. Hall, H.R., McCarty, C., Clark, M.W. (2014). Regulatory protection and definition for recreational uses of Florida lakes. Lake and Reservoir Management, 30(2), 115-118. doi:org/10.1080/10402381.2014.898349.

8. Hrek, N., Yukhnovskyy, I. (2005). Buti chi ne buti seredniomu klasu v Ukraïní [To be or not to be middle class in Ukraine?]. Mirror of the week, 17(54). Retrieved from http://www. dt.ua/img/st_img/2005/544/diag49961-1696-ukr.jpg.

9. Kachanov, V.S., Panasyk, L.V., Shukhov, N.S. (1989). Sotsial'no-ekonomicheskaya effektivnost' turistsko-rekreatsionnoy deyatel'nosti [Social and economic efficiency of tourist and recreational activities]. Social and economic problems of development of the sphere of tourist and excursion services in the 13th Five-Year Plan: All-Union. conf.: Abstracts. Moscow, VTSPS, Part 1, pp. 49-51.

10. Kantorovich, L.V. (1960). Ekonomicheskiy raschet nailuchshego ispol'zovaniya resursov [The economic calculation of the best use of resources]. Moscow, Publ. of the AS of the USSR, 347 p.

11. Kantorovich, L.V., Gorstko, A.B. (1968). Matematicheskoye optimal'noye programmirovaniye $v$ ekonomike [Mathematical optimal programming in Economics]. Moscow, Znanie, 96 p.

12. Kravtsiv, V.S., Hryniv, L.S., Kopach, M.V., Kuzyk, S.P. (1999). Naukovo-metodichni zasadi reformuvannya rekreatsiynoi sferi [Scientific-methodical foundations of recreational sector reform]. Lviv, NAS of Ukraine, $78 \mathrm{p}$.

13. Kysly, V.M., Shevchenko, H.M. (2008). Yekonomíchne znachennya ta napryamki vikoristannya regíonal'noí rekreatsíynoï renti [The economic importance and uses of regional recreational rent]. Visnik Sums'kogo derzhavnogo universitetu. Seríya Ekonomíka [Bulletin of Sumy State University. Economy Series], 2, 69-79.

14. Land Code of Ukraine; Regulation of Verkhovna Rada of Ukraine, No. 562-XII, 18.12.90. Retrieved from http://zakon.rada.gov.ua/cgi-bin/laws/main.cgi?nreg=561-12.

15. Lee, T.H., Jan, F.-H., Huang, G.W. (2015). The influence of recreation experiences on environmentally responsible behavior: the case of Liuqiu Island, Taiwan. Journal of Sustainable Tourism, 23(6), 947967. doi:10.1080/09669582.2015.1024257.

16. Li, J., Zhang, W., Xu, H., Jiang, J. (2015). Dynamic competition and cooperation of road infrastructure investment of multiple tourism destinations: a case study of xidi and hongcun world cultural heritage. Discrete Dynamics. Nature and Society, 10. doi:10.1155/2015/962028.

17. On Approval of the Strategy for Development of Tourism and Resorts for the Period until 2026 (2008); Order of CMU, 6.08.2008, No. 1088. Official Bulletin of Ukraine, No. 60, Art. 2041.

18. On the Resorts: The Law of Ukraine; Regulation of Verkhovna Rada of Ukraine, No. 2026-III, 05.10.2000. Retrieved from http://www.uapravo.net/data/base48/ukr48822.htm.

19. On the Tourism: The Law of Ukraine; Regulation of Verkhovna Rada of Ukraine, No. 325/95-VR, 15.09.95. Retrieved from http://zakon.rada.gov.ua/cgi-bin/laws/main.cgi?nreg=325\%2F95-\%E2\%F0.

20. Panchenko, T.F. (2001). Suchasniy stan, problemi zberezhennya ta perspektivi rozvitku ozdorovchikh $i$ rekreatsiynikh teritoriy Ukraini [Current status, problems and prospects of preserving health and recreational territories of Ukraine]. Kyiv: State Research and Design Institute of Urban Planning. Retrieved from http://www.eco-mir.com/246/.

21. Shevchenko, H.M. (2008). Kompleksna yekonomíchna otsínka prirodno-rekreatsíynogo potentsíalu teritorii. [Comprehensive economic evaluation of natural and recreational potential of the territory]. Kul'tura narodov Prichernomor'ya [Culture of the Peoples of the Black Sea], 135, 151-158.

22. State Statistics Service of Ukraine: official site. Retrieved from http://ukrstat.gov.ua/.

23. Yakovenko, I.M. (2005). O definitsiyakh teorii rekreatsionnogo prirodopol'zovaniya [About the definitions of the theory of recreational nature management]. Kul'tura narodov Prichernomor'ya [Culture of the Peoples of the Black Sea], 64, 22-27. 